\title{
Plasma Exchange for Primary Autoimmune Autonomic Failure
}

\author{
Christoph Schroeder, M.D., Steven Vernino, Ph.D., Andreas L. Birkenfeld, M.D., \\ Jens Tank, M.D., Karsten Heusser, M.D., Axel Lipp, M.D., Thomas Benter, M.D., \\ Carsten Lindschau, M.D., Ralph Kettritz, M.D., Friedrich C. Luft, M.D., \\ and Jens Jordan, M.D.
}

\section{SUMMARY}

We report on a patient with long-standing severe autonomic failure that affected his sympathetic and parasympathetic nervous systems. Antibodies against the ganglionic acetylcholine receptors were detected in the serum. Removal of the antibodies by means of plasma exchange resulted in a dramatic clinical improvement.

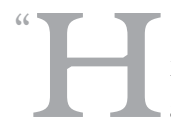

E IS A PINK COMPLEXIONED PERSON, EXCEPT WHEN HE HAS STOOD for a long time, when he may get pale and faint. His handshake is warm and dry. . . . He is thin because his appetite is modest; he never feels hunger pains and his stomach never rumbles. . . . As old age comes on he will suffer from retention of urine and impotence but frequency, precipitancy, and strangury will not worry him." Paton's description of the "hexamethonium man"1 illustrates the consequences of a pharmacologic blockade of ganglionic transmission. Hexamethonium blocks ganglionic nicotinic acetylcholine receptors, resulting in dysfunction of the efferent sympathetic and parasympathetic pathways. Disruption of these pathways causes severe orthostatic hypotension, anhydrosis, decreased production of saliva and tears, impaired bladder emptying, and erectile dysfunction. Patients with severe autonomic neuropathy have similar symptoms. Autonomic neuropathy can result from diabetes mellitus or amyloidosis, but in many patients no cause is evident. Occasional reports that intravenous immunoglobulins can be effective in autonomic neuropathy ${ }^{2-5}$ suggest an immune-mediated mechanism. ${ }^{6}$ The serum of some patients with subacute autonomic neuropathy contains autoantibodies against the ganglionic acetylcholine receptor, ${ }^{7}$ and autonomic dysfunction develops in rabbits that are immunized against the ganglionic acetylcholine receptor. ${ }^{8}$ These findings suggest that autoimmune autonomic neuropathy is an antibody-mediated neurologic disorder. However, a causal relation between anti-ganglionic acetylcholine receptor antibodies and autonomic failure has not been convincingly demonstrated in humans.

\section{CASE REPORT}

A 43-year-old man presented with recurrent orthostatic syncope. His symptoms had developed gradually over a 20-year period. Recently, he was unable to stand upright for more than a few seconds before fainting. He also reported decreased sweating, dry mouth, and urinary retention. He had difficulty focusing on near objects. Early satiety,
From the Franz Volhard Clinical Research Center and the Max Delbrück Center for Molecular Medicine (C.S., A.L.B., J.T., K.H., C.L., R.K., F.C.L., J.J.); the Department of Neurology (A.L.), Medical University Charité (C.S., A.L.B., J.T., K.H., C.L., R.K., F.C.L., J.J.); and Helios Klinikum (T.B.) - all in Berlin; and the Department of Neurology, University of Texas Southwestern Medical Center, Dallas (S.V.).

N EnglJ Med 2005;353:1585-90.

Copyright $\odot 2005$ Massachusetts Medical Society. 
painful abdominal distention, and severe constipation had resulted in weight loss. A partial smallbowel resection performed for suspected bowel obstruction was not beneficial. Surgery for retrograde ejaculations also failed to alleviate his symptoms. There was no history of an acute illness preceding this disorder, and there was no family history of autonomic dysfunction. Known secondary causes of autonomic failure had been ruled out. On physical examination he weighed $55 \mathrm{~kg}$ (with a body-mass index, defined as the weight in kilograms divided by the square of the height in meters, of 18.5) and had warm, dry skin. His pupils were dilated and unresponsive to light. The abdomen was painfully distended with sparse bowel sounds and a tympanic percussive sound. Imaging studies showed a grotesquely dilated ascending and transverse colon that had displaced the liver to the far left abdomen, with the stomach wedged between liver and spleen. Gastrointestinal passage, as determined by the ingestion of radiopaque pellets, was profoundly delayed.

METHODS

\section{ANTIBODY DETECTION}

Serum samples for antibody studies were collected before, during, and after treatment. Antibodies binding to neuronal ganglionic acetylcholine receptors were detected by a radioimmunoprecipitation assay. ${ }^{9}$ This assay uses a solubilized acetylcholine receptor from a human neuroblastoma cell line (IMR-32) that is labeled with a high-affinity radioligand, ${ }^{125}$ I-labeled epibatidine. The antigen-binding capacity of serum is expressed in nanomoles of 125I-epibatidine-receptor complexes precipitated per liter of serum. The upper limit of the normal range in serum is $0.05 \mathrm{nmol}$ per liter.

\section{PLASMA EXCHANGE AND IMMUNOSUPPRESSION}

Three liters of plasma was removed during each session through an 11-French double-lumen catheter with the use of a hollow-fiber plasma filter (PF 1000 N, Gambro). We replaced the removed plasma with 2.5 liters of 5 percent human albumin and 0.5 liter of fresh-frozen plasma. Because of relapses, the patient underwent repeated courses of plasma exchange. Each treatment consisted of plasma exchange on four consecutive days. After the second relapse, we started treatment with prednisolone (at a dose of $60 \mathrm{mg}$ per day) and azathioprine (at a dose of $100 \mathrm{mg}$ per day). Over time, the doses were reduced to $5 \mathrm{mg}$ of prednisolone per day and $50 \mathrm{mg}$ of azathioprine per day.

\section{AUTONOMIC FUNCTION TESTING}

Arterial blood pressure was measured continuously with the use of a radial-artery catheter. The heart rate was monitored with the use of electrocardiograms (Hewlett-Packard). The respiratory sinus arrhythmia ratio was determined as the ratio between the shortest and longest RR intervals during deep breathing paced at $6 \mathrm{~Hz}$. For the Valsalva maneuver, the patient exhaled forcibly into a manometer, maintaining a pressure of $40 \mathrm{~mm} \mathrm{Hg}$ for $15 \mathrm{sec}-$ onds. For the handgrip test, the patient squeezed a rubber ball with 30 percent of his maximal voluntary force. During the cold pressor test, the patient's right hand was immersed in a 1:1 mixture of ice and water for one minute. We assessed saliva production by measuring the increase in the weight of cotton swabs that were placed in the patient's mouth for five minutes. ${ }^{10}$ To assess orthostatic hypotension, the patient rested supine for at least 10 minutes, then stood and remained motionless until symptoms occurred. Microneurography at the peroneal nerve was performed as previously described. ${ }^{11}$

\section{PHARMACOLOGIC TESTING AND BAROREFLEX SENSITIVITY}

While monitoring arterial pressure, we infused incremental bolus doses of intravenous phenylephrine or nitroprusside until a change in the systolic blood pressure of $25 \mathrm{~mm} \mathrm{Hg}$ occurred. ${ }^{12}$ Baroreflex sensitivity was determined as the slope of the regression line of changes in blood pressure and corresponding changes in RR intervals.

\section{CONFOCAL FLUORESCENCE MICROSCOPY}

IMR-32 cells express neuronal ganglionic acetylcholine receptors. These cells were cultivated in 80 percent RPMI 1640 medium supplemented with 20 percent fetal-calf serum in chamber slides (Nunc). For measurements of intracellular calcium, cells were incubated with $5 \mu \mathrm{M}$ acetoxymethyl ester for $15 \mathrm{~min}$ utes at $37^{\circ} \mathrm{C}$, followed by two rinses and an additional incubation for 10 minutes. Measurements were performed on a confocal microscope (FluoView, Perkin-Elmer) with $488 \mathrm{~nm}$ excitation-collecting emission at $525 \mathrm{~nm}$ every second. We determined the intracellular calcium response of $0.1 \mu \mathrm{M}$ acetylcholine in the presence and absence of serum with a known antibody concentration. 


RESULTS

We tested the effect of the patient's antibodies on cholinergic responses of IMR-32 cells in vitro. The addition of $0.1 \mu \mathrm{M}$ acetylcholine induced a rapid increase in the level of intracellular calcium in these cells (Fig. 1). This response was attenuated when serum containing $0.001 \mathrm{ng}$ of anti-ganglionic acetylcholine receptor antibodies per milliliter was added to the cells, and it was virtually abolished with the addition of serum containing $0.1 \mathrm{ng}$ of the antibodies per milliliter. Incubation of the cells with serum obtained from a normal control subject produced no change in the intracellular calcium response to acetylcholine.

Figure 2 depicts concentrations of anti-ganglionic acetylcholine receptor antibody and orthostatic hypotension over 12 months and four courses of plasma exchange. The antibody concentrations were directly correlated with decreases in orthostatic blood pressure $\left(\mathrm{r}^{2}=0.41, \mathrm{P}<0.001\right.$ for systolic blood pressure; and $\mathrm{r}^{2}=0.51, \mathrm{P}<0.001$ for diastolic blood pressure) and correlated inversely with increases in orthostatic heart rate $\left(\mathrm{r}^{2}=0.33, \mathrm{P}=0.002\right)$. The mean concentration of anti-ganglionic acetylcholine receptor antibody before the plasma exchange was $0.54 \pm 0.02 \mathrm{nmol}$ per liter (10 times the upper limit of the normal range), a value consistent with autoimmune autonomic neuropathy. 9,13

During the course of the plasma exchange, the antibody concentrations decreased progressively to values within the normal range $(0.25 \pm 0.03$, $0.12 \pm 0.02,0.05 \pm 0.01$, and $0.03 \pm 0.01 \mathrm{nmol}$ per liter after days 1, 2, 3, and 4, respectively). With decreasing antibody concentrations, the orthostatic hypotension was markedly reduced and the orthostatic heart rate increased. After the third day of plasma exchange, the patient noticed improved orthostatic tolerance and had some return of sweating. After the fourth day, the symptoms had resolved completely. Dryness of the mouth and eyes improved, as did urinary hesitancy. Ejaculation became antegrade. The day after the last plasma exchange, the patient noticed "rumbling" in his abdomen, and the gastric distention and abdominal pain subsequently were relieved.

Before the plasma exchange, the heart rate did not change with deep breathing or during the Valsalva maneuver. The blood pressure decreased profoundly during phase II of the Valsalva maneuver. During phase IV, the pressure overshoot was absent. The handgrip test and the cold pressor test did not

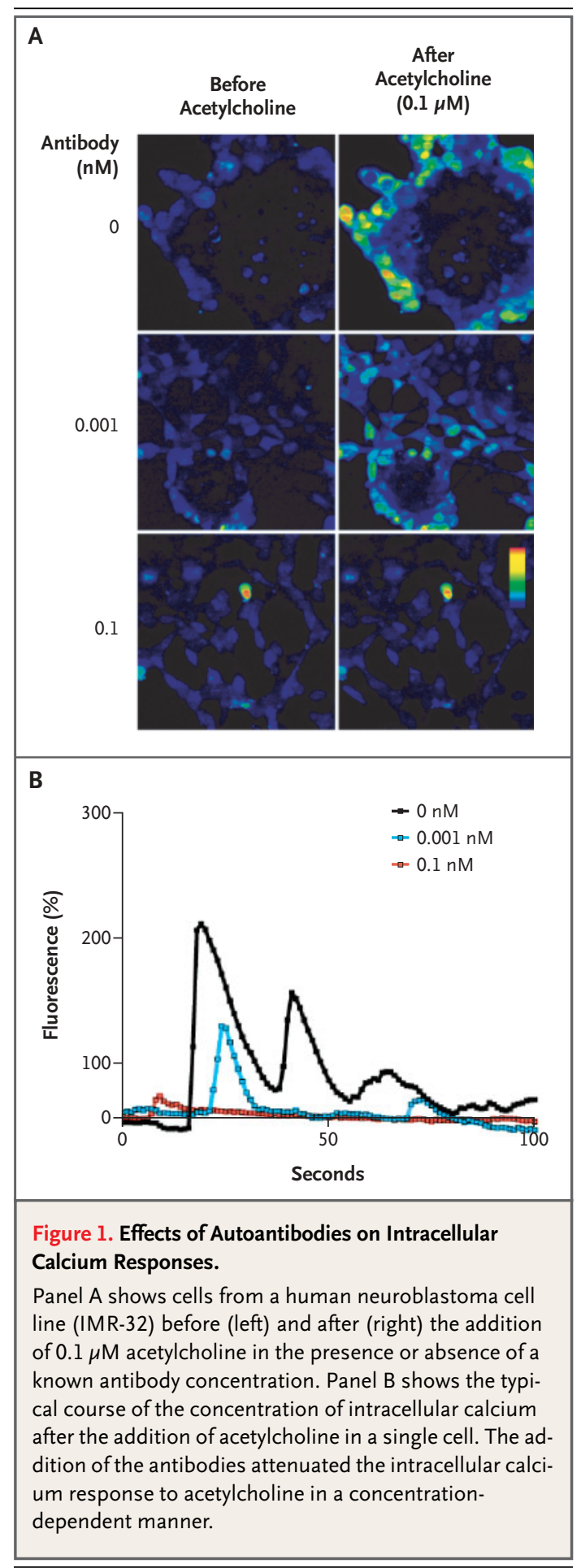

elicit a pressor response. Blood pressure was 137/72 $\mathrm{mm} \mathrm{Hg}$ in the supine position and 40/20 mm Hg after standing for 30 seconds (Fig. 3A). While the patient was supine, the norepinephrine plasma con- 


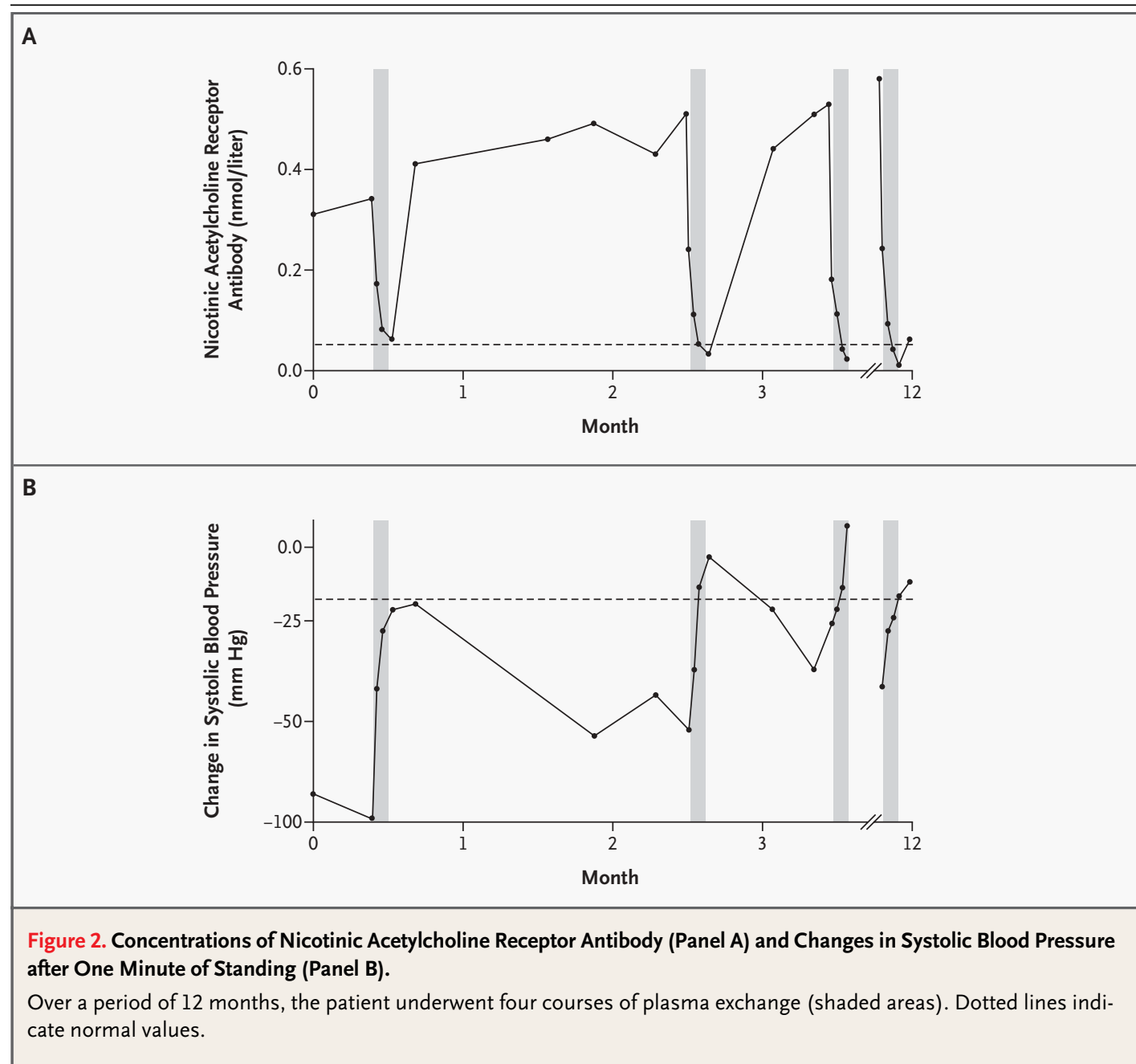

centration was very low $(0.23 \mathrm{nmol}$ per liter [ $38.9 \mathrm{pg}$ per milliliter]). The patient was very sensitive to pharmacologically induced changes in blood pressure. The dose of phenylephrine that increased systolic blood pressure by $25 \mathrm{~mm} \mathrm{Hg}$ was $28 \mu \mathrm{g}$. The dose of sodium nitroprusside that decreased blood pressure by $25 \mathrm{~mm} \mathrm{Hg}$ was $0.2 \mu \mathrm{g}$ per kilogram of body weight. Pharmacologically induced changes in blood pressure did not elicit an adequate compensatory baroreflex-mediated heart-rate response. The baroreflex slope was 0 msec per millimeter of mercury. Saliva production was low $(0.25 \mathrm{~g}$ within five minutes). No muscle sympathetic-nerve activity was recorded at the peroneal nerve.

One week after the plasma exchange, the patient's blood pressure was $132 / 68 \mathrm{~mm} \mathrm{Hg}$ in the supine position and 119/64 mm Hg after one minute standing (Fig. 3B). The heart rate increased appropriately, and the patient was able to stand up- right for more than 15 minutes without symptoms. The supine norepinephrine concentration had increased by a factor of three $(0.76 \mathrm{nmol}$ per liter [128.7 pg per milliliter]). Responses to the Valsalva maneuver were normal after the plasma exchange. Also after the plasma exchange, isometric handgrip elicited an increase in blood pressure of 20/17 $\mathrm{mm} \mathrm{Hg}$. The respiratory sinus arrhythmia ratio and cold pressor response remained abnormal. The doses of phenylephrine and nitroprusside that changed the systolic blood pressure by $25 \mathrm{~mm}$ Hg were $95 \mu \mathrm{g}$ and more than $1.0 \mu \mathrm{g}$ per kilogram, respectively. Both drugs elicited baroreflex-mediated changes in the heart rate. The baroreflex sensitivity had increased to $6 \mathrm{msec}$ per millimeter of mercury. Saliva production had increased by a factor of four $(1.1 \mathrm{~g}$ within five minutes). Minimal burst activity was recorded at the peroneal nerve (data not shown).

Four weeks after the first course of plasma ex- 


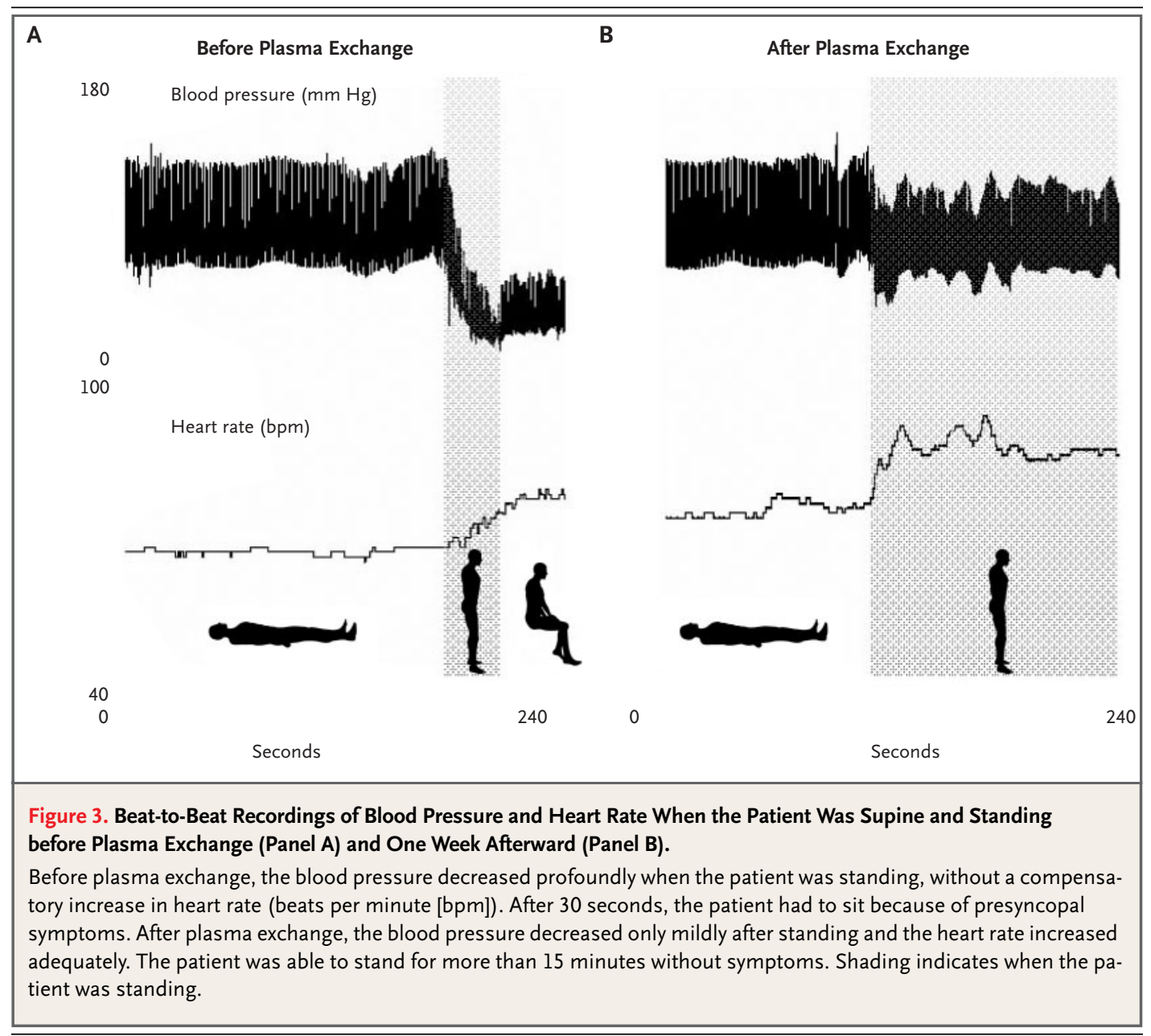

change, the patient's symptoms gradually recurred. The patient underwent a second course with similarly good clinical and serologic responses. After a second relapse, we started immunosuppressive therapy with prednisolone (at a dose of $60 \mathrm{mg}$ per day) and azathioprine (100 mg per day) and performed two more courses of plasma exchange. The clinical improvement with plasma exchange lasted eight months before a fourth course became necessary.

\section{I SCUSSION}

Our patient's history was remarkable for the progressive worsening of his symptoms over a period of more than 20 years. The type and severity of the autonomic deficits were typical of autoimmune autonomic neuropathy and affected both sympathetic and parasympathetic functions.

Signal transmission between the first and second neuron in both the sympathetic and parasym- pathetic branches relies on the same nicotinic acetylcholine receptors. The ganglionic acetylcholine receptor is a pentameric transmembrane complex usually consisting of two acetylcholine receptor subunits in combination with three acetylcholine receptor beta subunits. This acetylcholine receptor is a ligand-gated ion channel that mediates fast synaptic transmission in all peripheral autonomic ganglia. It is genetically and immunologically distinct from the acetylcholine receptor at the neuromuscular junction, which consists of two acetylcholine receptor alpha-1 subunits in combination with beta-1, delta, and epsilon subunits.

These differences explain why autonomic dysfunction is rare among patients with myasthenia gravis, ${ }^{14}$ and conversely, why our patient did not have skeletal-muscle weakness. Studies in animals showed that anti-ganglionic acetylcholine receptor antibodies can interrupt sympathetic and parasympathetic traffic, essentially acting as endogenous 
ganglionic blockers. ${ }^{15,16}$ In our patient, the antibodies inhibited cholinergic responses in cells expressing ganglionic acetylcholine receptors. An antibody that acts as an endogenous ganglionic blocker should reproduce physiological changes identical with those of pharmacologic ganglionic blockade. The orthostatic hypotension, decreased gastrointestinal motility, tonic pupils, and reduced plasma norepinephrine levels in our patient are typical effects of pharmacologic ganglionic blockade. ${ }^{17,18}$

The response in our patient to large-volume plasma exchanges supports the notion that primary autoimmune autonomic failure is directly caused by anti-ganglionic acetylcholine receptor antibodies and that the immunologic ganglionic blockade is potentially reversible. Plasma exchange improved both sympathetic and parasympathetic responses. In particular, upright blood pressure was better maintained and the patient's ability to stand increased dramatically. The improvement in orthostatic blood pressure and heart-rate regulation correlated with the decrease in the levels of anti- ganglionic acetylcholine receptor antibodies. Before plasma exchange, the patient was highly sensitive to pharmacologically induced changes in blood pressure with phenylephrine or sodium nitroprusside. Removal of the antibodies attenuated this sensitivity and was accompanied by improved baroreflex regulation of the heart rate. The response in our patient to plasma exchange supports the idea that he was indeed a "hexamethonium man." Ganglionic blockade by ganglionic anti-ganglionic acetylcholine receptor antibodies should be recognized as a cause of severe autonomic failure, and patients with autonomic failure that is not otherwise explained should be tested for presence of anti-ganglionic acetylcholine receptor antibodies.

Supported by grants from Deutsche Forschungsgemeinschaft (to Drs. Jordan, Kettritz, and Luft), Bundesministerium für Bildung und Forschung (to Drs. Jordan, Tank, Kettritz, and Luft), and Helmholtz Stiftung (to Dr. Luft) and by grants from Abbott, Novartis, and Sanofi-Aventis (to Dr. Jordan).

Dr. Jordan reports having received lecture fees from Abbott and Sanofi-Aventis.
REFERENCES

1. Paton WD. Transmission and block in autonomic ganglia. Pharmacol Rev 1954;6: 59-67.

2. Heafield MT, Gammage MD, Nightingale S, Williams AC. Idiopathic dysautonomia treated with intravenous gammaglobulin. Lancet 1996;347:28-9.

3. Smit AA, Vermeulen $M$, Koelman $\mathrm{JH}$ Wieling W. Unusual recovery from acute panautonomic neuropathy after immunoglob ulin therapy. Mayo Clin Proc 1997;72:333-5. 4. Venkataraman S, Alexander M, Gnanamuthu C. Postinfectious pandysautonomia with complete recovery after intravenous immunoglobulin therapy. Neurology 1998 51:1764-5.

5. Mericle RA, Triggs WJ. Treatment of acute pandysautonomia with intravenous immunoglobulin. J Neurol Neurosurg Psychiatry 1997;62:529-31.

6. Dalakas MC. The use of intravenou immunoglobulin in the treatment of autoimmune neuromuscular diseases: evidencebased indications and safety profile. Pharmacol Ther 2004;102:177-93.
7. Vernino S, Adamski J, Kryzer TJ, Fealey $\mathrm{RD}$, Lennon VA. Neuronal nicotinic ACh receptor antibody in subacute autonomic neuropathy and cancer-related syndromes. Neurology 1998;50:1806-13.

8. Lennon VA, Ermilov LG, Szurszewsk $\mathrm{JH}$, Vernino S. Immunization with neuronal nicotinic acetylcholine receptor induces neurological autoimmune disease. J Clin Invest 2003;111:907-13.

9. Vernino S, Low PA, Fealey RD, Stewar JD, Farrugia G, Lennon VA. Autoantibodies to ganglionic acetylcholine receptors in autoimmune autonomic neuropathies. $\mathrm{N}$ Eng J Med 2000;343:847-55.

10. Low PA. Testing the autonomic nervous system. Semin Neurol 2003;23:407-21.

11. Tank J, Schroeder C, Diedrich A, et al. Selective impairment in sympathetic vasomotor control with norepinephrine transporter inhibition. Circulation 2003;107: 2949-54.

12. Shannon JR, Jordan J, Black BK, Costa F, Robertson D. Uncoupling of the baroreflex by $\mathrm{N}(\mathrm{N})$-cholinergic blockade in dissecting the components of cardiovascular regulation. Hypertension 1998;32:101-7.

13. Klein CM, Vernino S, Lennon VA, et al. The spectrum of autoimmune autonomic neuropathies. Ann Neurol 2003;53:752-8.

14. Vernino S, Cheshire WP, Lennon VA. Myasthenia gravis with autoimmune autonomic neuropathy. Auton Neurosci 2001; 88:187-92.

15. Vernino S, Low PA, Lennon VA. Experimental autoimmune autonomic neuropathy. J Neurophysiol 2003;90:2053-9.

16. Vernino S. Ermilov LG, Sha L, Szurszewski JH, Low PA, Lennon VA. Passive transfer of autoimmune autonomic neuropathy to mice. J Neurosci 2004;24:7037-42.

17. Goldstein DS, Zimlichman R, Stull R, Keiser HR, Kopin IJ. Estimation of intrasynaptic norepinephrine concentrations in humans. Hypertension 1986;8:471-5.

18. Jordan J, Shannon JR, Black BK, et al. $\mathrm{N}(\mathrm{N})$-nicotinic blockade as an acute human model of autonomic failure. Hypertension 1998;31:1178-84

Copyright (C) 2005 Massachusetts Medical Society. 